\title{
Superior Capsular Reconstruction: A Literature Review About Comparison Auto- graft Using Long Head Biceps Tendon and Fascia Lata in Rotator Cuff Tear
}

\author{
Romy Deviandri*1, Aidil A. Nurshal ${ }^{2}$, Hanif Fahmat ${ }^{3}$
}

\begin{abstract}
ABSTRAK
Cedera otot supraspinatus masif merupakan salah satu cedera yang sering terjadi pada kelompok olahragawan. Pasien akan mengeluhkan nyeri serta kelemahan di bahu yang cedera. Terdapat banyak pilihan teknik untuk menangani cedera tersebut. Penelitian ini akan membandingkan penanganan cedera ini dengan teknik rekonstruksi menggunakan graft dari tendon long head biceps (LHB) dan tendon fascia lata (TFL). Penelitian ini merupakan studi literatur untuk membandingkan teknik dan outcome antara prosedur LHB dan TFL. Dari hasil penelitian, didapatkan hasil bahwa LHB lebih mudah untuk dilakukan dengan efek biomekanika yang sebanding dengan TFL, serta lebih baik dalam hal mencegah migrasi humeral head ke superior. Namun, TFL tampak lebih kuat dan penyembuhannya lebih baik karena mempunyai karakteristik dan struktur biomekanis yang lebih mirip dengan tendon supraspinatus. Kesimpulan penelitian ini, kedua teknik mempunyai keuntungan dan kerugian masing-masing. Namun, kedua teknik sama-sama mempunyai kemampuan yang baik serta dapat menjadi pilihan dalam penanganan cedera otot supraspinatus.
\end{abstract}

Kata Kunci: Rotator cuff tear, autograft, tensor fascia lata, long head biceps tendon, superior capsular reconstruction

The rotator cuff $(\mathrm{RC})$ is a primary dynamic stabilizer of the glenohumeral joint. Throughout the physiological shoulder range of motion, the RC maintains concentric reduction of the humeral head on the glenoid. When disrupted, the joint kinematics is altered, resulting in superior humeral translation, articular wear, and ultimately arthritis, known as a RC arthropathy. ${ }^{1}$ A rotator cuff tear (RCT) is a common pathology characterized by the tear of any one of the four tendons that compose the rotator cuff. The supraspinatus tendon, which inserts at the greater tuberosity, is most commonly affected, and a complete tear of the supraspinatus often results in pain, loss of function in arm abduction, and superior destabilization of the glenohumeral joint. ${ }^{2}$

The treatment of massive rotator cuff tears poses a challenge to orthopaedic surgeons. The reported prevalence of massive rotator cuff tears has been as

\footnotetext{
* Corresponding author: romydeviandri@lecturer.unri.ac.id

1 Department of Physiology, Universitas Riau, Pekanbaru, Riau, Indonesia

2 Division of Orthopaedic Surgery, Arifin Ahmad Hospital, Pekanbaru, Riau, Indonesia

3 Departement of Orthopaedic Surgery, Eka Hospital, Pekanbaru, Riau, Indonesia
}

high as $40 \%$ of all rotator cuff tears. Studies have indicated a higher rate of recurrent tearing for massive rotator cuff tears after surgery compared with smaller tears. The supraspinatus tendon, which inserts at the greater tuberosity, is most commonly affected, and a complete tear of the supraspinatus often results in pain, loss of function in arm abduction, and superior destabilization of the glenohumeral joint., ${ }^{2,3}$ Re-tear rates are high, $5-94 \%$, with risk factors such as age over 65 , fatty degeneration of over $50 \%$ of the rotator cuff muscle, tendon retraction, tobacco use, diabetes mellitus, and the size of the tear all predictive of structural failure of the repair. ${ }^{2}$

The De-Orio and Cofield classified massive rotator cuff tears as tears that are $>5 \mathrm{~cm}$ in size in either the anterior-posterior or medial-lateral dimension, whereas Gerber defined massive tears as those involving complete tears of at least 2 tendons. ${ }^{3}$

Roentgenographic grades of massive cuff tears were proposed. These were based chiefly on the acromio-humeral interval (AHI), which has been considered in the literature to be a sensitive indicator for the full-thickness cuff tear. An AHI of 6-7 mm was reported as the lower limit in normal shoulders by several authors. Five grades were classified; 
in Grade I, the AHI was more than $6 \mathrm{~mm}$, and in Grade 2, the AHI was $5 \mathrm{~mm}$ or less. In Grade 3, an acetabulization was added to the Grade 2 characteristics. The term acetabulization is defined by the present authors as a concave deformity of the acromion under surface. It has two subtypes; one is an excavating deformity of the acromion, and the other is a deformity formed by the excessive spur along the coracoacromial ligament. In Grade 4, narrowing of the glenohumeral joint was added to the Grade 3 features. Grade 5 comprised instances of humeral-head collapse, which is characteristic of cuff-tear arthropathy. ${ }^{4}$

Irreparable large to massive rotator cuff tears still pose a great challenge for many shoulder surgeons due to the poor outcome and lack of surgical options to restore cuff integrity. Various surgical options for massive rotator cuff tear were reported in the literature such as debridement and biceps tenotomy, tuberoplasty, partial repair, tendon transfer, patch graft, and reverse shoulder arthroplasty. ${ }^{5}$ Although rotator cuff tears can mostly be repaired with excellent results, some chronic large or massive rotator cuff tears are not reparable because of tendon retraction with inelasticity, muscle atrophy and fatty infiltration. ${ }^{6}$ The SCR has been proposed with the aim to restore superior glenohumeral stability and function in the shoulder joint affected with irreparable rotator cuff tears. ${ }^{7}$

In the original technique described by the Mihata et al, the superior capsule was reconstructed using a Tensor Fascia Lata (TFL) autograft that was harvested through an open approach. However, despite the reportedly promising clinical results of Superior Capsular Reconstruction (SCR) with a fascia lata autograft, concerns about donor site morbidity have discouraged orthopaedic surgeons from using this type of graft. ${ }^{8}$ During the last years, shoulder surgeons became interested in Mihata's original SCR technique, proposing some modifications, in particular regarding the choice of the graft, the presence of the long head of the biceps tendon (LHB), used as an autograft. ${ }^{7}$

The focus of this review is to comparing outcomes of SCR using TFL and using LHB as graft.

\section{SCR with TFL}

In Mihata et al.'s original case series, outside the time frame of this review update, the authors completely repaired the subscapularis tendon, partially repaired the infraspinatus and teres minor tendons, then performed SCR using a folded, 6-8$\mathrm{mm}$ thick fascia lata autograft. Two suture anchors were used for medial fixation to the superior glenoid and lateral fixation was done with the compression double-row technique. Their final step was to suture the graft posteriorly to the infraspinatus tendon and anteriorly to the residual supraspinatus or subscapularis tendons to improve force-coupling. TFL has similar biochemical and structural characteristics to supraspinatus (SS) tendon. Because of that, SCR with TFL has low rate of graft tear's incidence (Table 1). ${ }^{2,6,9}$

Table 1. The Advantages and risk of SCR using TFL.

\begin{tabular}{ll}
\hline Advantages & Risk \\
\hline - Similar biochemical and structural characteristics to SS & - Donor-site morbidity \\
- Low rate of graft tear & - Possible fracture of glenoid \\
- Good biological healing to the tendon & - Risk of cartilage damage \\
\hline
\end{tabular}

Abbreviation: SCR—Superior Capsular Reconstruction; TFL_Tensor Fascia Lata

\section{TFL with LHB}

In Arthroscopic Biceps Chillemi (ABC) technique, LHB tenotomy is performed distally maintaining intact its glenoid origin, so that our biceps graft is yet medially fixed. According to the surgeon preference and/or patients request is possible to perform a biceps tenodesis into the groove with a knotless anchor. Once repaired the subscapularis tendon if torn, at this point is possible to fix laterally to the greater tuberosity the LHB, choosing between a two-anchor or a two-trans-osseous tunnel fixation technique. Once the LHB is fixed, it is possible to perform a partial side-to-side repair of the residual cuff over the top of the biceps passing a suture through the infraspinatus tendon and into the poste- 
rior margin of the biceps. The LHB was more easier and feasible to perform. Nevertheless, there was an esthetic issue with this technique because of "the popeye appearance" $(\text { Table } 2)^{7}$

Table 2. Advantages and risk SCR using LHB., ${ }^{711,12}$

\begin{tabular}{|c|c|}
\hline Advantages & Risk \\
\hline - Without any donor site morbidity & - Popeye sign, an esthetic discomfort \\
\hline $\begin{array}{l}\text { - Anchor only at lateral side; easier, reduces operative time } \\
\text { and reduces the costs }\end{array}$ & $\begin{array}{l}\text { - Altering LHB biomechanics could lead to lesions } \\
\text { around the tendon origin (i.e.,SLAP lesion), which } \\
\text { in turn could be a source of pain }\end{array}$ \\
\hline $\begin{array}{l}\text { - No medial preparation of glenoid for SCR and no risk of } \\
\text { suprascapular nerve injury or possible cartilage damage } \\
\text { - LHB maintains its origin and vascular }\end{array}$ & \\
\hline
\end{tabular}

Abbreviation: SCR-Superior Capsular Reconstruction; LHB-Long Head Biceps

\section{DISCUSSION}

There was still debate between the outcome of SCR using TFL and LHB. As mentioned at table 4, both technique have a significant improvement in pain scale. Using TFL as graft shows better outcome, meanwhile using LHB is cost effective but needs further study. El-Shaar et al. ${ }^{1}$ in his cadaveric study concluded that SCR with an LHB autograft is a feasible procedure that is shown to be biomechanically equivalent and potentially even stronger than SCR with a TFL autograft in the prevention of superior humeral migration. SCR with an LHB autograft may prevent superior humeral migration and its associated conditions in patients with irreparable RC tears. Further clinical prospective studies are needed to compare clinical outcomes, specifically shoulder range of motion and strength, after SCR with an LHB autograft.

Table 3. Outcomes of SCR using TFL and LHB. ${ }^{7,8}$

\begin{tabular}{lcc} 
& TFL & LHB \\
\hline Study & 6 months follow up of 22 patients & 6 months follow up of 9 patients \\
VAS & 6.0 to 2.5 & 7.2 to 2.3 \\
ASES & 54.4 to 73.7 & NA \\
ROM (Abduction) & $53.2^{\circ}$ to $86.6^{\circ}$ & NA \\
ROM (Elevation) & $74.8^{\circ}$ to $104.5^{\circ}$ & NA \\
Graft tears & $9.1 \%$ & NA \\
Complaint & $57.1 \%$ patients were bothered by & Some patient felt uncomfortable at \\
& their harvested thigh & shoulder and upper arm \\
\hline
\end{tabular}

Abbreviation: VAS - Visual Analog Scale; ASES — American Shoulder and Elbow Surgeon Score; ROM-Range of Motion; TFL_-Tensor Fascia Lata; LHB_Long Head Biceps

\section{CONCLUSION}

Both techniques has pros and cons. There was still gap about the differences of the outcome among them. However, both techniques are sufficient and acceptable to be performed.

\section{REFERENCES}

1. El-shaar R, Soin S, Nicandri G, Maloney M, Voloshin I. Superior Capsular Reconstruction With a Long Head of the Biceps Tendon
Autograft: A Cadaveric Study. Orthop J Sport Med. 2018;6(7):1-4.

2. Wall KC, Toth AP, Garrigues GE. How to Use a Graft in Irreparable Rotator Cuff Tears: A Literature Review Update of Interposition and Superior Capsule Reconstruction Techniques. Curr Rev Musculoskelet Med. 2018;11(1):122130.

3. Greenspoon JA, Petri M, Warth RJ, Millett PJ. Massive rotator cuff tears: Pathomechanics, 
current treatment options, and clinical outcomes. J Shoulder Elb Surg. 2015;24(9):1493-1505.

4. K. Hamada, H. Fukuda, M. Mikasa YK. Roentgenographic Findings in Massive Rotator CuffTears. Clin Orthop Relat Res. 1990;(254):926

5. Lim S, AlRamadhan H, Kwak JM, Hong H, Jeon IH. Graft tears after arthroscopic superior capsule reconstruction (ASCR): pattern of failure and its correlation with clinical outcome. Arch Orthop Trauma Surg. 2019;139(2):231239.

6. Mihata T, McGarry MH, Pirolo JM, Kinoshita M, Lee TQ. Superior capsule reconstruction to restore superior stability in irreparable rotator cuff tears: A biomechanical cadaveric study. Am J Sports Med. 2012;40(10):2248-2255.

7. Chillemi C, Mantovani M, Gigante A. Superior capsular reconstruction of the shoulder: the $\mathrm{ABC}$ (Arthroscopic Biceps Chillemi) technique. Eur J Orthop Surg Traumatol. 2018;28(6):1215-1223.

8. de Campos Azevedo CI, Ângelo ACLPG, Vinga S. Arthroscopic Superior Capsular
Reconstruction With a Minimally Invasive Harvested Fascia Lata Autograft Produces Good Clinical Results. Orthop J Sport Med. 2018;6(11):1-13.

9. Mihata T, Lee TQ, Watanabe C, et al. Clinical results of arthroscopic superior capsule reconstruction for irreparable rotator cuff tears. Arthrosc - J Arthrosc Relat Surg. 2013;29(3):459470.

10. Rosales-Varo AP, García-Espona MA, Roda-Murillo O. Outcomes of rotator cuff augmentation surgery with autologous fascia lata. Rev Española Cirugía Ortopédica y Traumatol (English Ed. 2018;62(3):157-167.

11. Boutsiadis A, Chen S, Jiang C, Lenoir H, Delsol P, Barth J. Long Head of the Biceps as a Suitable Available Local Tissue Autograft for Superior Capsular Reconstruction: "The Chinese Way." Arthrosc Tech. 2017;6(5):e1559-e1566.

12. Pauzenberger L, Hurley ET. Finally, Something Positive About the Long Head of the Biceps Tendon? Shoulder Superior Capsular Reconstruction. Arthrosc - J Arthrosc Relat Surg. 2018;34(9):2601-2603. 